Send your letters to the Editor,

British Dental Journal,

64 Wimpole Street

London

W1G 8YS

Email bdj@bda.org

Priority will be given to letters less than 500 words long.

Authors must sign the letter, which

may be edited for reasons of space.

\section{AN URGENT NEED}

Sir, Patel et al. ${ }^{1}$ have raised a valid point about the fundamental nature of undergraduate oral surgery education. The Association of British Academic Oral and Maxillofacial Surgeons (ABAOMS) national education group ${ }^{2}$ recently published an undergraduate oral surgery syllabus ${ }^{3}$ that addresses Patel et al.'s concern.

The syllabus outlines a need for competence in surgical extractions and it exemplifies the type of procedure graduates should be able to perform. The syllabus and the education group's input to the DentEd III project have influenced the recently updated 'Profile and Competencies for the European Dentist ${ }^{4}$ which also stipulates the need for competence in surgical extractions.

In addition to the syllabus the ABAOMS national education group has just completed a national survey of all 2009 dental graduands. Part of this survey examines respondents' perceived level of competence in the various stages comprising a surgical extraction. The data collected are currently being analysed and will be published in the near future.

It is important to ensure that our graduating dental students are competent in oral surgical skills; however, it is equally important to understand what 'competent' means. One of the more concise definitions is, '...when [an individual is] capable of functioning independently with a degree of contingency solving in realistic practice'. ${ }^{5}$

Competence is, however, a dynamic, fluctuating journey and the time to expert status has been estimated at ten years. ${ }^{6}$ This is not ten years of undergraduate experience, which forms only part of the journey but is probably proportionally represented within these ten years. Postgraduate experience where the trainer:trainee ratio is $1: 1$ will form a large part of these ten years and is therefore vital in building towards and developing expertise.

In the limited time scale of the undergraduate course it is difficult to imagine that students will become experts in any clinical skill. Dental schools are probably attempting to raise the unconsciously incompetent to the status of conscious competent (Fig. 1), or to put it another way the 'safe beginner'. Exposing students, in a controlled manner, to experiences that enable them to make reasoned judgements as to whether or not they can undertake treatment should be our first aim.

The first five years ${ }^{7}$ - the third, interim edition fronted with an apposite illustration of a lighthouse in the $\operatorname{fog}^{8}$ - delivers guidance to safety, in this case towards safe practice. It is, therefore, imperative that practitioners should understand the boundaries of their competence, "putting patients' interests first and acting to pro-

\begin{tabular}{|l|l|l|}
\hline \multirow{3}{*}{ Perfect skills } & $\begin{array}{l}\text { Expert } \\
\text { (Unconsciously competent) }\end{array}$ & $\begin{array}{l}10 \text { years of practice } \\
\text { (Chi et al. 1998) }^{6}\end{array}$ \\
\hline & $\begin{array}{l}\text { Competent } \\
\text { (Consciously competent) }\end{array}$ & (Realistic) work setting \\
\cline { 2 - 3 } & $\begin{array}{l}\text { Beginner } \\
\text { (Application of skills whilst } \\
\text { consciously incompetent) }\end{array}$ & $\begin{array}{l}\text { Simulation. Supervised } \\
\text { practice }\end{array}$ \\
\hline \multirow{3}{*}{ Prepare for skills } & $\begin{array}{l}\text { Novice } \\
\text { (Consciously incompetent) }\end{array}$ & Attain basic knowledge \\
\cline { 2 - 3 } & $\begin{array}{l}\text { Candidate } \\
\text { (Unconsciously incompetent) }\end{array}$ & \\
\hline
\end{tabular}

Fig. 1 Journey to competence. Adapted from Chambers \& Glassman ${ }^{15}$ and Hendricson \& Kleffner ${ }^{16}$ tect them' ( $p$ 5). ${ }^{8}$ This may be what Patel et al. have found in their survey.

At Newcastle University's School of Dental Sciences we have demonstrated that it is possible to achieve and assess competence in exodontia and minor oral surgical skills. ${ }^{9-11}$ We are, however, on the basis of a recent survey, only one of six schools in the UK to summatively assess forceps exodontia, and one of four schools to summatively assess surgical extractions. ${ }^{12}$

In our oral surgery clinical assessments we are not expecting students to demonstrate expertise. We expect them to demonstrate the knowledge, and the ability, to perform the stages of the procedure proficiently and safely, solving contingencies that arise within reason. For instance a root displaced into the antrum is a well-recognised complication of simple extraction but newly graduated or even some experienced practitioners might prefer to refer this to a specialist unit.

The results presented by Patel et al. are interesting and have allowed discussion of some important points but the 
45\% response rate, amongst other methodological considerations, casts doubt over whether the results can be considered a true reflection of their sample's perceptions. We concur with Patel et al. that undergraduate education in oral surgical skills is imperative, but would add that our own work has shown this to be labour and time intensive. Given that low levels of staff in academic oral and maxillofacial surgery have been demonstrated by several recent publications it may be Patel et al.'s results show that there is an urgent need to invest more in this area. ${ }^{12-14}$

U. J. Moore

J. A. Durham

P. J. Thomson Newcastle

1. Patel $S, E v a n s, F$, Mckechnie A. Fundamental training. Br Dent J 2009; 207: 51.

2. ABAOMS national education group's pages. 2009 Available at http://www.abaoms.org.uk/Pages/ UgUKEduc.htm accessed 31 July 2009.

3. Macluskey M, Durham J, Cowan G et al. UK national curriculum for undergraduate oral surgery. Eur J Dent Educ 2008; 12: 48-58.

4. Cowpe J, Plasschaert A, Harzer W et al. Profile and Competences for the European Dentist - update 2008. Available at http://www.adee.org/cms/ uploads/adee/01\%20TF_I_PCEDupdateAug081. pdf. Accessed 2 August 2009

5. Chambers D W, Gerrow J D. Manual for developing and formatting competency statements. J Dent Educ 1994; 58: 361-366

6. Chi M T H, Glaser R, Farr M J. The nature of expertise. Hillside, New Jersey: Erlbaum, 1998.

7. Murray J FS, Frame J, Green R et al. The first five years - a framework for undergraduate dental education. General Dental Council, 2002.

8. GDC. The first five years - third edition (Interim) 2008. Available at http://www.gdc-uk.org/ NR/rdonlyres/485E9B5A-A9CB-438E-A920E3907E0A8E63/91357/TFFYthirdeditionfinal1.pdf. Accessed 2 August 2009

9. Anziani H, Durham J, Moore U. The relationship between formative and summative assessment of undergraduates in oral surgery. Eur J Dent Educ 2008; 12: 233-238.

10. Durham J A, Moore U J, Corbett I P et al. Assessing competency in dentoalveolar surgery: a 3-year study of cumulative experience in the undergraduate curriculum. Eur J Dent Educ 2007; 11: 200-207.

11. Moore U, Durham J, Corbett I et al. The influence of staffing and timetabling on achieving competence in surgical extractions. Eur J Dent Educ 2009; 13: 15-19.

12. Macluskey M, Durham J. Oral surgery undergraduate teaching and experience in the United Kingdom: a national survey. Eur J Dent Educ 2009; 13: 52-57.

13. Fitzpatrick S. Staffing Levels of Medical Clinical Academics in UK Medical and Dental Schools. 2009. Available at http://www.medschools. ac.uk/AboutUs/Projects/Documents/DSC\%20 Clinical\%20Academic\%20Staff\%20Survey $\% 20$ July\%202008.pdf. Accessed 2 August 2009.

14. NHS. Workforce summary - Oral Surgery. Available at http://www.wrt.nhs.uk/index.php/component/docman/doc_download/25-oral-surgery. Accessed 2 August 2009

15. Chambers D W, Glassman P. A primer on competency-based evaluation. J Dent Educ 1997; 61: 651-666.

16. Hendricson W D, Kleffner J H. Curricular and instructional implications of competency-based dental education. J Dent Educ 1998; 62: 183-196.

DOI: 10.1038/sj.bdj.2009.964

\section{OIL HYGIENE}

Sir, I read the letter to the editor on oil therapy (BDJ 2009; 207: 193) and I would like to add some more information. Oil pulling or oil swishing is an old Ayurvedic method which was popularised by $\mathrm{Dr}$ F. Karach in the 1990s in Russia. In this therapy sunflower, sesame or another cold pressed refined oil is preferred because commercial oils are extracted with strong petroleum based solvents and heated to $450^{\circ} \mathrm{F}$. Such heat changes the excellent monounsaturated (oleic acid) fats to trans fats which are harmful to the body but there are no molecules of solvent and trans fatty acids present in cold pressed sesame oil.

Sesame (Sesamum indicum L., Pedaliaceae) is a very old cultivated crop thought to have originated in Africa and the oil contains three lignans - sesamin, sesamolin and sesaminol - that increase both the hepatic mitochondrial and the peroxisomal fatty acid oxidation rate. Sesame seed consumption appears to increase plasma gamma-tocopherol and vitamin $\mathrm{E}$ activity which is believed to prevent cancer and heart disease. ${ }^{1}$ Sesamin inhibits the absorption of cholesterol as well as its production in the liver, reduces lipogenesis and exhibits an anti-hypertensive action.

Oil pulling therapy is found to be very effective even in maintaining oral health for various reasons. Sesame oil is a vegetable fat and when it is acted upon by the salivary alkali, like bicarbonates, the soap making process (saponification) is initiated. Soaps are good cleansing agents because they are effective emulsifying agents. Emulsification is the process by which insoluble fats like sesame oil can be broken down into minute droplets and dispersed in water enhancing the surface area of oil and thereby increasing its cleansing action. The viscosity of oil also helps in the prevention of bacterial adhesion and co-aggregation. ${ }^{2}$ Sesame oil is found to have antibacterial activity against $S$. mutans and Lactobacilli ${ }^{3}$ and antifungal action due to the presence of Chlorosesamone obtained from the roots of sesame. ${ }^{4}$ Sesame oil contains high amounts of polyunsaturated fatty acids which reduce free radical injury to the oral tissues. ${ }^{5}$ Therefore it could be useful for maintaining oral hygiene. Sesame oil has other advantages as it causes no staining, has no lingering aftertaste, and causes no allergic reactions.

A. Parolia Mangalore

1. Cooney R V, Custer L J, Okinaka L, Franke A A. Effects of dietary sesame seeds on plasma tocopherol levels. Nutr Cancer 2001; 39: 66-71.

2. Asokan S, Rathan J, Muthu M S, Rathna PV et al. Effect of oil pulling on Streptococcus mutans count in plaque and saliva using Dentocult SM Strip mutans test: a randomized, controlled, tripleblind study. J Indian Soc Pedod Prev Dent 2008; 26: 12-17.

3. Durai Anand T, Pothiraj C, Gopinath R M, Kayalvizhi B. Effect of oil-pulling on dental caries causing bacteria. African J Microbiol Res 2008; 2: 63-66.

4. Begum S, Furumoto T, Fukui H. A new chlorinated red naphthoquinone from roots of Sesamum indicum. Biosci Biotechnol Biochem 2000; 64: 873-874.

5. Namiki M. The chemistry and physiological functions of sesame. Food Rev Int 2002; 11: 281-329.

DOI: 10.1038/sj.bdj.2009.965

\section{TREAT YOUR WALLET}

Sir, I feel my worst fears have been confirmed. I recently was at an end of term function, my table of ten consisted of myself, 'one of the aged school', plus nine of the younger generation. The conversation was totally a comparison of how much money each could extract for the least amount of work. I listened to this mercenary tirade for half an hour then I expressed my disgust as not once did I hear the words patient care. When I expressed my disgust to them I met a chorus of abuse as to how old fashioned I was.

The norm now is treat your wallet.

I constantly hear people complain about dentists' attitudes and expense, little wonder that even MPs have a better press than us.

Without doubt, dentistry is now a trade not a profession.

A. R. Jukes

Plymouth

DOI: $10.1038 /$ sj.bdj.2009.966

\section{FLAWED CONCLUSION}

Sir, we have noted the letter by Y. Zanganah (BDJ 2009; 207: 96) and consider that his conclusion concerning the importance of radiographs is flawed. 
He states that radiographs in general practice are part of a clinical examination, however, they should not be taken routinely. There must be a clinical justification for every radiographic exposure. ${ }^{1}$

A complaint of 'discomfort in the region of the lower left wisdom tooth' is probably not best investigated with an orthopantomograph (DPT) but rather with an intra-oral image or a DPT with field limitation. ${ }^{2}$

If a dentist plans to refer a patient for specialist advice and/or treatment it may be correct not to expose radiographs. However, if radiographs have already been taken it is essential to forward them to the specialist. ${ }^{3}$

\section{A. R. Thom, K. Isaacson}

By email

1. The lonising Radiation(Medical Exposure) Regulations 2000 (IR(ME)R). London, HMSO

2. Rushton VE, Horner K. The use of panoramic radiology in dental practice. J Dent 1996; 24: 185-201.

3. Selection Criteria for Dental Radiography.

FGDP(UK) Good Practice Guidelines. 2004. Faculty of General Dental Practitioners (UK).

DOI: 10.1038/sj.bdj.2009.967

\section{FIGHTING FOR FREEDOM}

Sir, thank you for your bold editorial Whatever happened to trust? (BDJ 2009; 207: 93). I agree with your observation about the Government's obsession with legislation and control, euphemistically known as regulation.

Haven’t we been here before? Doesn't socialism always end up with totalitarian control? There are also similarities with fascism.

The library of economics and liberty has this article in the Concise Encyclopedia of Economics, from which I quote:

'Under fascism, the state, through official cartels, controlled all aspects of manufacturing, commerce, finance, and agriculture. Planning boards set product lines, production levels, prices, wages, working conditions, and the size of firms. Licensing was ubiquitous; no economic activity could be undertaken without government permission. Levels of consumption were dictated by the state, and "excess" incomes had to be surrendered as taxes or "loans". From Fascism by Sheldon Richman.

I think a change of government may help, and trust would certainly help, but judging by the international nature of this problem, we may all end up fighting for our freedom again.

A. Rhodes DOI: 10.1038/sj.bdj.2009.968

\section{EFFICIENT, HIGH QUALITY}

Sir, the article authored by Brandlish and Mariatos (BDJ 2009; 207: 111-115) illustrates the many possible benefits of 'direct-wax' cast gold onlays.

Today, there is much concern worldwide with dental professionals being able to deliver long-lasting and predictable restorations to a large population in a cost-effective manner. Cast gold onlays have historically proven to be an excellent restoration which can be viewed as a preferred option to full-coverage restorations - onlays are more conservative and, hence, preserve more natural tooth structure.

The added advantages of 'direct -wax' cast gold onlays of decreased laboratory expenses and decreased operator time make it a technique which has the possibility of providing efficient, high quality dentistry to many individuals.

W. Maloney

New York

DOI: 10.1038/sj.bdj.2009.969

\section{SAVING MORE LIVES}

Sir, Dr H. Frenkel (BDJ 2009; 207: 4-5), and Dr A. Korada (BDJ 2009; 206: 396), among others, have described the 'terrible condition' of oral health among people living in care homes, and pointed out that oral hygiene is often insufficient among the residents. However, the consequences of neglected oral care have not been thoroughly disseminated among dental, medical and nursing professionals. Therefore, the hitherto published research evidence that indicates a strong relationship between insufficient oral hygiene and healthcareassociated pneumonia (nosocomial pneumonia) among nursing home residents and hospitalised elderly is briefly summarised below.

In a systematic review in 2006, it was concluded that there is strong evidence that improved oral hygiene and frequent professional oral care reduces the progression or occurrence of respiratory tract diseases among highrisk elderly living in nursing homes and intensive care units (relative risk reduction 34-83\%). ${ }^{1}$

In another, recent, systematic review, it was concluded that there is strong evidence that mechanical oral hygiene leads to about 9-11\% absolute risk reduction for mortality from pneumonia, and to a clinically obvious preventive effect on healthcare-associated pneumonia among nursing home residents and hospitalised elderly, with about 7\% absolute risk reduction. ${ }^{2}$

Translated to numbers needed to treat, approximately one out of ten cases of death from pneumonia among these individuals could be prevented by improving their oral hygiene. ${ }^{2}$ The oral hygiene measures studied were: weekly conducted professional oral hygiene, or tooth brushing after every meal, alone, or in combination with daily $1 \%$ povidone iodine scrubbing of pharynx..$^{3-5}$ A plausible mechanism for the infection pathway in healthcare-associated pneumonia is silent aspiration of respiratory pathogens from the oral cavity and oropharynx into the lung.

In light of the available evidence, the importance of oral care cannot be overlooked. Individual oral care needs to be integrated in the care-chain of hospitalised or nursing home resident elderly. This is not only a matter of saving lives but can also lead to a considerable net gain in care costs; money which then can be used to save other lives.

P. Sjögren,

O. Johansson,

J. Hoogstraate,

M. Forsell

By email

1. Azarpazhooh A, Leake J L. Systematic review of the association between respiratory diseases and oral health. J Periodontol 2006; 77: 1465-1482.

2. Sjögren $P$, Nilsson $E$, Forsell $M$, Johansson 0 , Hoogstraate J. A systematic review of the preventive effect of oral hygiene on pneumonia and respiratory tract infection in elderly in hospitals and nursing homes: effect estimates and methodological quality of randomized controlled trials. J Am Geriatr Soc 2008; 56: 2124-2130.

3. Yoneyama T, Hashimoto K, Fukuda H, Ishida M et al. Oral hygiene reduces respiratory infections in elderly bed-bound nursing home patients. Arch Gerontol Geriatr 1996; 22: 11-19.

4. Yoneyama T, Yoshida M, Matsui T, Sasaki H. Oral care and pneumonia. Lancet 1999; 354: 515.

5. Adachi M, Ishihara K, Abe S, Okuda K, Ishikawa T. Effect of professional oral health care on the elderly living in nursing homes. Oral Surg Oral Med Oral Pathol 2002; 94: 191-195.

DOI: $10.1038 /$ sj.bdj.2009.970 